\title{
Reflections of an Irish Pracademic: Mixing Public Advocacy, Teaching and Research?
}

\author{
MARY P. MURPHY \\ Maynooth University, Ireland
}

ABSTRACT This article reflects on the challenges of mixing public advocacy, teaching, and research in Irish third level education. It explores the concept of academic activism and introduces concepts of 'public sociologist' and 'pracademic' to contextualize my own academic trajectory and activism. Having reflected on general academic activism in the context of challenges facing Irish civil society, the focus then shifts to a personal case study. The conclusion addresses the ambiguities and tensions of pursuing a particular approach to academic life. The need for academic activism is intensifying in the context of the neoliberalization of Irish universities, a weakening civil society, and a more precarious academic life.

KEYWORDS academic activism; Ireland; civil society; managerialism; pracademic

Ever tried. Ever failed. No matter. Try Again. Fail again. Fail better.

(Beckett, 1983, p. 1; emphasis in original)

\section{Introduction}

In this article I critically explore the relationship between scholarship and activism with regard to the challenges of incorporating a commitment to social justice into pedagogical and research work both inside and outside an Irish university. From the safety and perspective of secure tenure, I draw on concepts of 'public sociology' and 'pracademic' to help make sense of my own experience, and then reflect on contemporary Irish academic activism within the broader literature on academic activism, civil society, and democracy. I describe my journey into academic activism in three areas: public engagement and advocacy, pedagogy, and research. I then discuss key challenges facing Irish academics engaged in activism in the context of significant trends in Irish civil society and the emerging policy context for 
civic engagement in third level education. The conclusion reflects on how tenure is necessary to make the mixing of advocacy, policy work, and academic labour a sustainable option.

\section{Pracademic or Activist?}

Scholar-activists, for the purposes of this article, are academics working as both teachers and researchers in third level institutions, while also being activists striving for progressive or more radical social change. Various literatures define and unpack the concept of scholarly activism with subtle differences in their emphasis and level of ambition for the term. Here I attempt to situate my own academic trajectory and circumstances in the literature on scholarship and activism. Sudbury and Okazawa-Rey (2009, in Mitchell, 2009, p. 98), for example, see scholarly activism as the "production of knowledge and pedagogical practices through active engagements with, and in the service of, progressive social movements." The Autonomous Geographies Collective ( 2010) makes use of Pain's (2003) categorisation of three approaches for the public intellectual interested in making change. The first approach "fuses politics and academic research agendas into one coherent strategy and methodology and works closely with resisting others and social movements" (2010, p 248), the second approach stresses forms of participatory research, and the third approach is based on more critical forms of policy-oriented research (2010, p. 249).

These conceptualisations of scholarly activism are useful and reflect to some degree my own approach to academic work. In another significant contribution, Croteau (2005) distinguishes between different styles of activism: SCHOLAR-Activists who, although genuinely concerned about the contributions of their scholarship to emancipatory goals, primarily prioritize the academic value of their work; scholar-ACTIVISTS who stress activism over scholarship; and SCHOLAR-ACTIVISTs who keep such roles separate and unintegrated. What I find most useful about Croteau's configurations is that they are not understood as mutually exclusive. Over time, academics move between categories and may keep some aspects of activism separate whilst choosing to more fully integrate other forms of activism into their academic life. I can identify with this experience of moving between approaches and integrating some, but not all, activist campaigns into academic life. Piven (2010, p. 806) is less interested in politically-oriented 'public intellectuals' who manage to be relevant without damaging their scholarly success (i.e., Croteau's SCHOLAR-activist category), and is more concerned with scholarly action committed to advancing the interests and ideas of groups at the margins of public life (i.e., scholar-ACTIVISTS). This is a type of dissident activism that, Piven argues, creates substantial tension with academic careers. I cannot characterise my work in terms of this more radical definition of dissident scholar-activism. 
Apple (2011, pp. 46-48) helpfully outlines how he thinks scholar-activists should position themselves in the university. To paraphrase Apple, an activist must not only open up the university to society, but must also struggle against unequal power relations on and off campus, highlight spaces of possible action within and beyond the university, redefine research toward transformative reforms, challenge the content of elite knowledge, engage in critical traditions of radical work, seek to develop skills and work at many levels with multiple groups, collaborate with those struggling, and blend such activism with excellent research. Acknowledging that one cannot engage in all nine of these fronts simultaneously or evenly, he argues that scholaractivists must at least attempt to practice them. Apple's framework offers inroads to reflexively and critically examining academic labour. Applying it to my own labour, I find I fall short in meeting his expectations to the degree that I am somewhat wary of self-identifying as a scholar-activist.

Although Chatteron and Pickerill (2010) stress the importance of avoiding exclusive use of the label and promote accommodating a wide range of approaches within the terminology of scholar activist, I am nevertheless reluctant to use the term scholar-activist to describe my approach. This may be in part because of my own path into academic life. In Ireland, the term activist and the expression 'academic activist' is often used in the social movement domain and within particular political and intellectual traditions and discourses. Although approaches to activism originate from different theoretical traditions, most self-described scholar-activists appear to be explicitly informed by praxis, combining theory or analyses and practice to achieve intentional change. Inspired by Freirean approaches to education (Mayo, 2012), these individuals base their politically engaged pedagogy on Freire's belief in the potential of education to liberate through problemposing rather than problem-solving (Freire, 1996). Freirean activist-oriented strategies grounded in communities are often contrasted with those that focus on working through non-governmental organizations (NGOs) and institutional policy processes (e.g., taskforces, commissions, expert groups), which are often viewed as perpetuating the status quo or advancing neoliberalism (Townsend, Porter \& Mawdsley, 2002). Hearne (2014, p. 4), for example, argues that Irish NGOs are dependent on the ideology of the elite system and resist opportunities to "unleash the popular resistance that radical change requires." While such a sharp line cannot be drawn between Freirean activist-oriented strategies grounded in communities and the institutional-oriented work of many NGOs, there is nonetheless an important question of how and where academics locate themselves in different intellectual and political traditions of struggle, and how this then manifests in their workplace. Smeltzer and Cantillon (2015, p. 12), commenting on the "revolution to reform spectrum," argue that "many individuals occupy viewpoints in the middle of the spectrum and alter their approach depending on myriad factors, including the issue at hand, personal obligations, and professional commitments." While their observation reflects my own 
experience it is still the case that, as someone who has tended to work from more reformist positions and who has at times tactically chosen to be inside institutional sites of power (as well as being often outside), I want to avoid making false claims in describing myself as an scholar-activist.

To make sense of my own experience as an academic committed to the pursuit of social justice who sometimes works through institutional routes, I first explore Burawoy's concept of 'public sociology,' and then Volpe and Chandler's (2001) understanding of 'pracademic.' The first category I draw on comes from within my own discipline, for which Burawoy (2005, p. 259) differentiates between public, policy, professional, and critical sociologies. While public sociology is committed to engaging in multiple public "dialogues around issues raised in and by sociology" (2005, p. 266), policy sociology is "sociology in the service of a goal defined by a client," which aims to "to provide solutions to problems that are presented to us, or to legitimate solutions that have already been reached" $(2005$, p. 266). The third approach, professional sociology, provides the underlying framework for other forms of sociology by supplying "true and tested methods, accumulated bodies of knowledge, orienting questions, and conceptual frameworks" (2005, p. 267). Critical sociology confronts and addresses institutionalized "biases" and "silences" within professional sociology and promotes "new research programs built on alternative foundations" (2005, p. 268). Burawoy further differentiates the traditional public sociologist, whose work "instigates debates within or between publics, although he or she might not actually participate in them" (2005, p. 264), from the organic public sociologist. The latter works in a process of mutual education and dialogue with various publics and "in close connection with a visible, thick, active, local and often counter-public" (2005, p. 264). The overarching goal of the organic public sociologist is to contribute to transformative change and promote a critical imagination about the world and possible alternatives to the status quo. Examining my own work, I find elements of at least three of these approaches - the critical, the policy, and the organic public sociologist - and agree with Burawoy's (2005) observation that although these approaches can at times be complementary, they are also in tension with each other. I have found that while "policy sociology can turn into public sociology" (Burawoy, 2005 , p. 267), it is also often resistant to a more politicized critical sociology or the public work of an organic public sociologist.

The term 'pracademic' describes scholars who have professionally bridged the academic and practical world, particularly those who go into academia having already established a career as a practitioner (Volpe \& Chandler, 2001), which in my case constituted a 20-year career in anti-poverty and equality NGOs, and a six-year period as an elected Dublin City Councillor. My role as a 'pracademic' can be distinguished from the voluntary role of the 'activist' to the degree that as a pracademic I crossed professional or workplace boundaries between the university and another sector. This mixed experience of working in 'insider' sites of institutional power means I am 
sensitive to the difficulty of achieving meaningful or transformational change, and have gained critical insight into the use and operation of power whilst also experiencing the dangers of co-option (Lewis, 2008). This work experience brings valid knowledge to bear on my academic research work and civil society activism. I explore later how this route of entry into academia impacts my approach to and experience of scholar-activism.

\section{The Academic in Irish Civil Society}

Having situated my own academic trajectory and circumstances in relation to some prominent literature on scholarship and activism, I now turn to where scholar-activists fit into Irish civil society, which has been overshadowed by a weak but controlling state that in the last two decades has tried to inhibit advocacy and activism (Murphy, 2012). Kirby and Murphy (2011, pp. 143148) identify four trends that characterize recent Irish state and civil society interaction: (a) the state has co-opted, disempowered, and attempted to lock Irish civil society into narrow understandings of what is possible; (b) the state has imposed ever more disciplinary funding regimes; (c) civil society has shifted from advocacy about redistributive justice and social change to more managerialist service provision models; and (d) there is a more restricted public sphere with less capacity for public debate and political discourse.

The resultant loss of proactive energy in civil society over recent years is evident in the relatively muted Irish societal responses to austerity, ${ }^{1}$ a trend that is also apparent in other countries. As Fraser (2014) argues, across the globe we are living through a crisis of great severity and complexity, but we lack the critical theory or conceptual frameworks necessary to interpret it or resolve it in an emancipatory way. Our capacity, she contends, is undermined by an absence of solidarity and the tendency to treat crises in the realms of political economy, ecology, and social reproduction as unconnected. This lack of solidarity is indicative of "fragmented imaginations" that are caused in part by the degree to which the media separately analyzes and reports different parts of our political and economic worlds (Preston \& Silke, 2011, p. 11). Concomitantly, elites conjure up circumstances that fragment society and limit the possibility of social solidarity on such issues as pay cuts and taxation (e.g., creating discourses that divide public and private sector workers; see Allen, 2012, p. 428). Moreover, as Carney, Scharf, Timonen \& Conlon (2014) maintain, family solidarity in Ireland trumps society- or community-based solidarity.

In Ireland, as elsewhere, critical scholarship can play an important part in 'joining the dots' and offering new possibilities for political imagination that might, in turn, trigger new solidarities and foster the critical consciousness

\footnotetext{
${ }^{1}$ But note the 2014-2015 Irish water protests, which are evidence of a reignited form of political advocacy (Hearne, 2015).
} 
necessary to help generate social change (Fraser, 2014; Mayo, 2012). To thrive in this fashion, civil society needs resources that are independent of the state, as well as the capacity to organize itself in state-free spaces. Lynch (2010) argues that academics clearly have a leadership role to play in forging and creating these spaces, and in supporting civil society to resist threats. In a similar vein, Mayo (2012) asserts that universities can be emancipatory, and he celebrates the long tradition of intellectuals resisting corporate values, and promoting social justice and human dignity (Mayo \& Borg, 2007). However, elsewhere Mayo (cited in Juha, 2010, p. 121) is more cautious about the university's emancipatory potential, recognising the degree to which it is "a site of struggle in which relations of hegemony are consolidated or challenged with a view to renegotiation." Exploring whether academics can offer new possibilities for political imagination, Lynch (2010) is also realistic about the degree to which the university's cultural reproduction of the elite, and its legitimation of hegemonic common sense, limits its possibility as a site for emancipatory change. In other words, the contemporary university has to be understood in the context of contemporary financialized capitalism where democracy has been captured by the financial elite (Rajan, 2010).

Moreover, over the last two decades, the capacity of academics to contribute to the public sphere has increasingly been inhibited by the global development of a more managerialist style of public university (Lynch, Grummell \& Devine, 2012). Slippage in the potential role of universities as sites for transformation is a feature of an increasingly silent Irish society where recent policy shifts have resulted in the loss of a transformative focus for Irish higher education (Murray, Grummell \& Ryan, 2013). Lynch, Grummell \& Devine (2012) and Loxley (2014), for example, point to how commercialization and new public management mechanisms and metrics, such as ranking and outcome indicators, create regimes that stifle sociopolitical activism. These regimes require more onerous accountability, productivity, and administrative demands in ever-compressed time frames, thereby producing working conditions that deny autonomy, creativity, collaboration, and care (Lynch, Grummell \& Devine, 2012; Mountz et al., 2015). As a result of such trends, Irish academic social activism has decreased over recent years (O'Shea \& O'Brien, 2011). It is notable too that Irish academics have not engaged in the same level of anti-austerity electoral politics as is the case in other EU states such as Greece and Spain (Scarpetta, 2014).

Nevertheless, many Irish academics continue to use the academy to promote equality and social justice, and as the evidence in these special issues of Studies in Social Justice attest, do so in different forms and styles of liberal, critical, emancipatory, and radical scholarship, as well as in other methods of on-the-ground action. Having set this wider context of Irish academics and civil society, the next section attempts to make sense of my own experience of Irish academic activism as I examine in turn my approach to public advocacy, pedagogy, and research. 


\section{Personal Trajectory}

I entered academic life in my mid-40's, having spent two decades working in NGOs and in political society. The factors motivating entry into an academic position have a significant bearing on how any scholar negotiates the rewards and challenges, successes and drawbacks of pursuing activist endeavours in the academy. Since the 1980's, my working life has been essentially linked to activity in civil and political society, and connected to social justice-related campaigns and projects. When I graduated with a $\mathrm{PhD}$ in 2006, I had no significant academic career ambition or concept of a preferred sector; rather, I sought to position myself somewhere with "levers" to contribute to social change (Lewis, 2008, p. 570). In 2007, I had to choose between two public sector job offers: a tenured academic position and a permanent research management position in a statutory national anti-poverty agency. The independence and flexibility offered in the academy won the day; the academic world appeared to me to be a place with "levers" and a workplace "where I can do the stuff I want to do" (Lewis, 2008, p. 570) in terms of public engagement and advocacy, teaching, and research.

\section{Public Engagement and Advocacy}

Since the mid-1990's, I had been a regular commentator on income policy for national radio and television news and current affairs programs. Entering Irish academic life with this clear orientation, my appointment coincided with the 2008 economic crisis. As a new professor (i.e., permanent lecturer grade in Ireland) and an emerging organic public sociologist, I continued to provide public commentary in the new context of austerity. This public-oriented role requires a thick skin. Although my perspectives are welcomed by various publics, my work has been both dismissed as biased by those who publicly identify me as a female left-wing commentator, and critiqued by various commentators on the left for insufficiently promoting radical alternatives to austerity or capitalism. Moreover, my motivation is questioned by those who suspect that such engagement is prompted by desire for the limelight or connection with elite media networks. I am also ambivalent about my own participation; although I believe my contribution has at times broken some silences, offered solidarity, and promoted political imagination, I often find participation futile, regret decisions to participate, and more recently tend to decline such invitations. At the same time, I remain conscious as a public academic that the media are a key site of power where Irish women's voices and gendered analysis are too infrequently heard. Over time, I have offered to mentor and support new women's voices, and in 2015 worked with Claiming Our Future to co-design and co-deliver 'Cap the Gap,' an eight-day activist 
training workshop for 25 people interested in publicly campaigning for income equality (Claiming our Future, 2015). ${ }^{2}$

Having joined the academy in 2007 , I continue my participation in various civil society equality networks. This includes a significant level of "back office" work (Smeltzer \& Cantillon, 2015, p. 12), collaborating with various NGOs in housing, social welfare, taxation, and labour market campaigns. As an organic public sociologist, I also contribute to developing new spaces for public engagement, including Claiming Our Future and new budget campaigns that promote the values of solidarity, equality, and sustainability (Murphy, 2012). Although I am motivated primarily by the end goal of such campaigns, I also enjoy the sense of collaborative collective action and endeavour involved - a feeling that is often absent in the more individualized practice in the academy. Reflecting on what I gain from such work I am reminded of Piven's (2010, p. 810) advice to be mindful of the "joy political work gives us," because, she says:

Even when we fail, working to make our society kinder, fairer, more just, gives a satisfaction like no other, because the comrades we find in the effort are friends like no other, and also because our activist efforts illuminate our social and political world in ways that scholarship alone never can. (Piven, 2010, p. 810)

\section{Pedagogy}

Although there is growing pressure on academics to produce research outputs, our fundamental role is still to educate. In the context of this mandate, Edwards contrasts what he calls "university factories" with what he poetically describes as "a social science of love," which promotes "an intelligence of the heart" and "personal transformation" of the learner into a civic actor with "deep respect for others" (2007, p. 20-21). Engaging in emancipatory forms of education and putting social value into learning directly challenges the neoliberal idea of the university as an institution that solely serves the so-called knowledge economy (Coate \& MacLabhrainn, 2007; Lynch, 2010; O'Shea \& O'Brien, 2011).

In 2006, the Maynooth University Department of Sociology developed an undergraduate degree program in Politics and Active Citizenship, which employs a critical pedagogical approach to exploring politics 'beyond the usual.' In 2007 I was employed, with others, to develop the degree, including delivery of an innovative experiential learning module that aims to offer students an opportunity to observe the contestation and preservation of power

\footnotetext{
${ }^{2}$ Claiming Our Future was founded in 2010 as a national non-party-political network of individuals and civil society organizations; "it aims to promote and make real the values of equality, environmental sustainability, participation, accountability, and solidarity" (Claiming Our Future, 2015)
} 
in the 'real world,' and so fosters the development of students as critical active citizens. Since 2008, approximately 20 political science students per year have undertaken this module in the second semester of their second year, and almost 150 students have participated since its inception. Over one semester, these students choose 'power actors' in political worlds outside the university. They spend 30 hours over the course of two months shadowing these actors while keeping a learning journal documenting their experience. They then theorize and reflect on their learning experiences in 12 facilitated workshops. Students find their own placements, with academic support as necessary. After eight years, the module is now well-embedded as a mandatory component of a politics undergraduate program, delivered by the Department of Sociology.

The Department of Sociology, which houses the module, is committed to the type of "public sociology" described above (Burawoy, 2005). The module therefore focuses on an active learning experience for students, but does not incorporate an ambition for community service; indeed, there is wariness of active citizenship concepts that promote volunteering as an alternative to critical public and political debate (Geoghegan \& Powell, 2007). The aim is for students to have an opportunity to experience and reflect on power and democracy in the external world. This is consistent with Boland's (2013, p. 214) advocacy to promote an "affective domain" - a teaching and learning environment that provides students with "opportunities to explore and interrogate their own values and preconceived ideas about the nature of the social world."

Class readings and discussion vary considerably depending on which instructor leads the module. My pedagogy, for instance, is informed by Kolb's cycle of active learning, reflection, theorizing, and experimentation (Kolb, 1984). Drawing on Kolb's framework, I use the module to promote collective learning, where the educator has authority but does not engage in authoritarian top-down teaching (Freire, 1996; Mayo, 2012). Workshop sessions are "a series of dialogues" (Burawoy, 2005, p. 266), which are ideally led by the students' own reflections about what they observe, and thus only work with their active participation. This dialogical approach is challenging for many students who have become accustomed to rote learning, and as a result a small number of them have not thrived in such an experiential learning environment. On the whole, however, feedback about the module is very positive. Students' evaluations stress that they enjoyed having an opportunity to apply theory to reality. Students have told me that the module is the learning experience they think they will remember most from their degree. Students are proud of their individual learning outcomes, such as their first argument with a politician, a public presentation, becoming a candidate in local elections, securing employment working in policy processes, joining campaigns, or speaking in a public meeting. There is clear evidence of activist flowering amongst some students, which we hope will continue in the long-term. 
This type of critical pedagogy needs to be protected from wider national and university aspirations for a more shallow and instrumental form of 'community engagement,' which has been endorsed as part of Ireland's National Strategy for Higher Education (Department of Education and Skills, 2011, p. 77). According to Campus Engage Ireland, a national network which aims to promote civic engagement as a core function of Irish higher education, 'community engagement' is "a mutually beneficial knowledgebased collaboration between the higher education institution and the wider community, through community-campus partnerships including the activities of community-based learning, community-engaged research, volunteering, community and economic regeneration, capacity building and access/widening participation" (Campus Engage, 2014, p. 3). This instrumental approach is compatible with neoliberal managerialism, with some champions of community engagement also advocating performancerelated funding, and accountability metrics including key performance indicators for community engagement (Campus Engage, 2014, p. 26-27). Such an approach is also consistent with the overall liberal communitarian approach to democracy and active citizenship as outlined in the Irish national policy statement, Supporting Voluntary Activity (DSFCA, 2000), which conflates critical civic engagement with volunteering (Geoghegan \& Powell, 2007). Critical pedagogy also has to be protected from students' demands for employment-oriented internships, a common and legitimate feature of instrumental university education, but one not to be confused with experiential education aimed at social transformation (Craig, 2015; Smeltzer, 2015).

\section{Research}

My research activity includes participation as a policy sociologist in a number of policy forums, including the National Advisory Group on Taxation and Social Welfare (2011-2014), and since 2013, the Irish Human Rights and Equality Commission (IHREC). Responding to government invitations to participate in policy forums is of course never straightforward, especially considering that many are 'smoke screens' to legitimate elite agendas. Without parallel campaign strategies to mobilize agency, working though institutional channels rarely generates transformative social change. At the same time, such work has relevance. As McCabe argues, "the current battle over the resources of the state needs to be engaged with" (2013, p. 55), and policy participation can yield valuable insights, data, and opportunities (albeit limited) to advance arguments. As a critical sociologist I have been commissioned by women's organizations and trade unions to work with them to research labour market and social security policy and develop campaigns. However, I have not pursued commissions from statutory bodies with restricted terms of reference that limit the form of knowledge that might be 
created. Nevertheless, there are compromises in maintaining a critical and organic public sociology role, and in preserving access to elite policy spaces. Although I straddle three of Buroway's (2005) four types of sociology, over time I feel I have been transitioning from policy sociology toward critical sociology and organic public engagement. My research focus is shifting away from generating instrumental policy knowledge focused on problem solving, and toward the more reflexive knowledge associated with critical and public sociology (Burawoy, 2005, p. 269).

It is not clear to me whether or how such a transition in roles might interact with my academic career. More than one well-meaning mentor has advised me that I will not be credited for activist work in promotion applications. Although I am not averse to promotion, my definition of academic success is not confined by its parameters. To some extent, I still have some choices in how I prioritize my academic time. There are opportunity costs: activism can impinge on time to publish, to pursue academic networking and research funding, and to contribute to internal university service commitments. But this does not mean research activity and funding opportunities are sacrificed or that academic endeavours are neglected. Indeed, in relation to promotion and career advancement there are also positives to engaging in activist pursuits. As well as contributing to collective endeavours, I benefit personally and professionally from such work. These experiences help inform and test my theoretical and conceptual frameworks and enhance my teaching, as well as my students' learning experiences. The university likewise benefits from such work in terms of reputation and exposure. Indeed, it is somewhat ironic that in the new academic marketplace, where academics compete for external resources and publications, even transformative research can be commodified as a realistic target for academic capitalism (Lynch, 2010; Slaughter \& Leslie, 1997).

Nevertheless, there are practical difficulties and ethical compromises involved in translating organic public or critical sociology work into academic outputs and publications. Acknowledging the ethical and practical difficulties involved, I have to a limited extent been able to draw on knowledge secured through policy and campaign work to contribute to academic publications. Activism has also enabled access to research networks and funding opportunities. I have applied for Pan-European and European Union funded research programs, and in 2015 was part of a successful consortium awarded a 2.5 million Euro funding grant under the Horizon 2020 Euro (3) European Societies after the Crisis funding program. Our project is using a participatory research approach involving a merging of knowledge between academics, civil society, and citizens experiencing poverty. My collaboration in this project emerged in part through my activism and organic public sociology; specifically, my involvement with Claiming Our Future opened the door to the EU level Alliances Against Poverty activist network from which the application originated. 


\section{Conclusion: Reflecting on Activist Scholarship}

This article has sketched my journey into an academic career, a trajectory driven in part by a pursuit of social justice and motivated by the opportunities the academy offers for activism and public engagement. As noted above, the university "is where I can do the stuff I want to do" (Lewis, 2008, p. 570). The process of interrogating my structural location as a pracademic and as a critical, policy, and organic public sociologist has been challenging, and has highlighted for me the complexities and contradictions of my choices, as well as the need for persistent reflection. As mentioned earlier, maintaining a presence as a policy sociologist in relatively elite institutions does not sit easily with critical sociology or the role of an organic public sociologist. While there are clear advantages to engaging in some aspects of policy sociology, such as policy innovation and rich networking opportunities, there are also risks of co-option into old roles and power relationships (Lewis, 2008, p. 569). That said, my life and work experience, as well as my relatively late entry into the academy, means less prospect of loyalty to the elite academy or its dominant hegemonic values, and some ability to cope with myriad practical challenges associated with activist scholarship.

Some of these challenges involve managing the ambiguous feedback or opinions of colleagues. Although many are supportive and offer practical assistance, some are uneasy with public forms of scholarship and advocacy. Some dislike or distrust such engagement, fearing it compromises the academic environment or the perceived neutrality of academic research (Wickham, 2012). A further tension exists between academics who traverse the different traditions of left activism and are often each other's most ardent critics. In addition, there are challenges posed by increased managerialism, and the risk that regardless of entry point or age, institutional capture can over time divert original ambitions and aspirations (Croteau, 2005). Mountz et al. (2015), Loxley (2014), and Lynch, Grummell \& Levine (2012) describe how the growing administrative and professional demands of fast-paced, metric-oriented, neoliberal universities disrupt intellectual growth and personal freedom, as well as hinder collaborative and communal work. Indeed, virtually all aspects of academic life are vulnerable to institutional capture, commodification, marketization, and academic capitalism (Lynch, Grummell \& Levine, 2012), and academic freedom is also increasingly under threat in this context (Docherty, 2015; Karran, 2007; Lynch, 2010; Russell, 1993). Over eight years I have experienced this intensification of a culture of individualism that feeds into ever more stringent promotion criteria, which reward research funding and a narrow range of publications, as well as other forms of academic activity that are less than conducive to activism.

Civic participation may be tolerated, and in some cases encouraged, but the valid form of knowledge it generates is under-valued. Piven (2010, p. 809) thus advises fellow scholars to think "carefully about where we place ourselves in a complex and variegated academic world," and to be mindful of 
how where we are "will affect our ability to do the political work to which we are committed." Maynooth University, while subject to the intensification of managerialism, remains a relatively collegial space. A critical mass of academics at the institution is committed to working for social transformation and there are spaces which offer the potential for solidarity and collegiality, including a relatively new research cluster called Social Justice, Participation and Human Rights, which focuses on "addressing social justice, participation and human rights through research, learning and professional practice" (Maynooth University, 2015). As Ryan observes, "stamina is required of the educator as critic, commentator, activist, engager, and visionary; the traps associated with each of these roles can derail the educator from the project of justice" (2011, p. 99). Reflecting on my own experience I realise how little I have sought or utilised opportunities to reflect with other academics. The cluster and other spaces provide opportunities for individual and collective reflection, and for highlighting possible action within and beyond the university.

There is also the practical issue of time. As Goldrick-Rab (2014, p. 1) attests, "it takes time, energy, emotional labour, and a thick skin" to maintain scholarly activism. The challenge of combining academic commitments and public sociology must be integrated with the everyday reality of caring, especially in female academics' lives. From a feminist "ethic of care" perspective, Mountz et al. (2015) discuss the need to claim time for slow scholarship, and to maintain collective collaborative action informed by feminist politics. Similarly, Petrick (2015, p. 10) discusses "how the availability of time, as well as intellectual and emotional space, to engage in academic or activist work is often determined by the ebbs and flows of one's personal life." As a middle-aged female feminist academic, I find myself in the 'pincer' moment where time for activism not only competes with academic pressures, but also has to be reconciled with the complex needs of teenage children and an ageing parent. I struggle in this context to find room for competing priorities. In 2015, three well-respected Irish middle-aged female academics resigned from tenured positions, privately acknowledging their ambition to work in ways that are both more socially transformative and accommodating of care in their lives. Although security of tenure allows me some room to manoeuvre through these challenges and contradictions, those on precarious contracts face multiple barriers to engaging in any form of academic activism. Those of us fortunate enough to have tenure can choose to some degree how to negotiate this terrain, and for me the university remains a viable workplace where I can fulfil different roles and ambitions (Lewis, 2008, p. 570). However, there is a whole new generation of Irish scholars who have to pursue academic activism in the context of precarious short-term or low-hour contracts. The precarity of this rising class of academic labour leaves little space for academic activism (Courtois \& O'Keefe, 2015). This loss is not just a concern for young academics but for 
the academy more generally, for civil society, and for anyone who aspires to a more equal and sustainable world.

\section{Acknowledgments}

I would like to acknowledge the support I get from various colleagues in academic, community and personal settings, and also thank the various reviewers of this article for generous feedback and for alerting me to a wide range of literature. I particularly want to thank the editors of the special issues, Sandra Smeltzer and Sara Cantillon, for the opportunity to reflect on the challenges and contradictions of the triple shift of scholarship, activism and care, and for their support, guidance and above all patience through the publication process.

\section{References}

Allen, K. (2012). The model pupil who faked the test: Social policy in the Irish crisis. Critical Social Policy, 32, 422-439.

Apple, M. (2011). Paulo Freire and the tasks of the critical educational scholar/activist. In A. O'Shea \& M. O'Brien (Eds.), Pedagogy, oppression and transformation in a 'post-critical' climate: The return of Freirean thinking (pp. 36-51). London: Continuum.

Autonomous Geographies Collective (2010). Beyond scholar activism: Making strategic interventions inside and outside the neoliberal university. ACME: An International EJournal for Critical Geographies, 9, 245-274.

Beckett, S. (1983). Worstward ho. New York: Grove Press.

Boland, J. (2013). Curriculum development for sustainable civic engagement. In C. O Farrell \& A. Farrell (Eds.), Emerging issues in higher education III: From capacity building to sustainability (pp. 210-225). Dublin: EDIN.

Burawoy, M. (2005). Public sociology. American Sociological Review, 70(4), 1-28.

Campus Engage (2014). Irish higher education civic and community engagement: National consultation report. Dublin: Campus Engage.

Carney, G.M., Scharf, T., Timonen, V., \& Conlon, C. (2014). 'Blessed are the young, for they shall inherit the national debt': Solidarity between generations in the Irish crisis. Critical Social Policy, 34, 312-332.

Chatterton, P., \& Pickerill, J. (2010). Everyday activism and transitions towards post-capitalist worlds. Transactions of the Institute of British Geographers, 35, 475-490.

Claiming Our Future (2015). CAP the GAP. Dublin: Claiming Our Future. Retrieved from http://www.claimingourfuture.ie/events/latest/2015/01/06/cap-the-gap-activist-training/

Claiming Our Future (2015). Claiming our Future: About Us. Dublin: Claiming Our Future. Retrieved February 72016 from http://www.claimingourfuture.ie/about/

Coate, K., \& MacLabhrainn, I. (2007). Irish higher education and the knowledge economy. In L. Ilrath \& I. MacLabhrainn (Eds.), Higher education and civic engagement: International perspectives (pp. 208-215). Aldershot: Ashgate.

Courtois, A., \& O'Keefe, T. (2015). Precarity in the ivory cage: Neoliberalism and casualization of work in the Irish higher education sector. Journal for Critical Education Policy Studies, 13(1), 43-66.

Craig, J. (2015, September). Teaching politics in our universities: Linking academic study and practice. Paper presented at the Political Science Association of Ireland Conference, Dublin, Ireland. 
Croteau, D. (2005). Which side are you on? The tension between movement activism and scholarship. In D. Croteau, W. Hoynes \& C. Ryan (Eds.), Rhyming hope and history: Activists, academics and social movement scholarship (pp. 224-240). Minneapolis: University of Minnesota Press.

Department of Education and Skills. (2011). National strategy for higher education to 2030. Dublin: Government Publications Office.

Department of Social, Community and Family Affairs (DSCFA). (2000). White paper on a framework for supporting voluntary activity and for developing the relationship between the state and the community and voluntary sector. Dublin: Government Publications Office.

Docherty, T. (2015, March). On free speech and academic freedom: Responsibilities and complicities. Paper presented at the Maynooth University English Department Seminar, Maynooth, Ireland.

Edwards, M. (2007). Love, reason and the future of civil society. In L. Ilrath \& I. MacLabhrainn (Eds.), Higher education and civic engagement: International perspectives (pp. 13-25). Aldershot: Ashgate.

Fraser, N. (2014). Can society be commodities all the way down? Post-Polanyian reflections on capitalist crisis. Economy and Society, 43 (4), 541-558.

Freire, P. (1996). Pedagogy of the oppressed. London: Penguin Books.

Geoghegan, M., \& Powell, P. (2007). Active citizenship, civil society and the enabling state: Political myth or democratic reality? Administration, 55(3), 31-51.

Goldrick-Rab, S. (2014). Contexts. Retrieved December 4, 2014 from http://contexts.org/blog/on-scholarly-activism/

Hearne, R. (2014, October 3). No revolution please. We are Irish. Village. Retrieved from http://www.villagemagazine.ie/index.php/2014/10/the-failure-of-irish-social-partnershipand-soft-ngo-advocacy/

Hearne, R. (2015). The Irish water war, austerity and the 'Risen People'. NIRSA Working Paper, Department of Geography, Maynooth University, Ireland.

Juha, S. (2010). Against the corporate culture ideology: An interview with Peter Mayo. Review of Education, Pedagogy, and Cultural Studies, 32(1), 112-126.

Karran, T., (2007). Academic freedom in Europe: A preliminary comparative analysis. Higher Education Policy, 20(3), 289-313.

Kirby, P., \& Murphy, M.P. (2011). Towards the Second Republic; Irish politics after the Celtic Tiger. London: Pluto Ireland.

Kolb, D.A. (1984). Experiential learning: Experience as the source of learning and development. Englewood Cliffs: Prentice Hall.

Lewis, D. (2008). Using life histories in social policy research: The case of third sector/public sector boundary crossing. Journal of Social Policy, 37(4), 559-578.

Loxley, A. (2014). Measures and metrics and academic labour. In J. Walsh, A. Loxley \& A. Seery (Eds.), Higher education in Ireland: Practices, policies and possibilities (pp. 123145). London: Palgrave McMillan.

Lynch, K. (2010). Lessons for higher education: The university as a site of activism. British Journal of Sociology of Education, 31(5), 575-590.

Lynch, K., Grummell, B., \& Devine, D. (2012). New managerialism in education: Commercialization, carelessness and gender. Basingstoke: Macmillan Palgrave.

Maynooth University (2015). Research strategy. Maynooth: Maynooth University. Retrieved from www.maynoothuniversity.ie/research/social-and-economic-transformations/socialjustice-participation-human-rights

Mayo, P. (2012). Critical pedagogy today: Echoes from Freire for a critically engaged pedagogy. Huntingdon: Bloomsbury Academic.

Mayo, P., \& Borg, C. (2007). Public intellectuals, radical democracy and social movements: A book of interviews. New York: Peter Lang.

McCabe, C. (2013). Transforming capitalism through real utopias: A critical engagement. Irish Journal of Sociology, 21(2), 51-61.

Mitchell, J. (2009). Activist scholarship: A review of three recent works. Social Justice, 36(4), 98-101. 
Moutz, A., Bonds, A., Mansfield, B., Loyd, J., Hyndman, J., Walton-Roberts, . . Curran, W. (2015). For slow scholarship: A feminist politics of resistance through collective action in the neoliberal university. ACME: An International E-journal for Critical Geographies. 14(4), 1235-1259.

Murphy, M.P. (2011). Civil society in the shadow of the Irish state. Irish Journal of Sociology, 19(2), 170-187.

Murphy, M.P. (2012). Participation and deliberation: A case study of Claiming Our Future. In G. Carney \& C. Harris (Eds.), Citizens' voices: Experiments in democratic renewal and reform (pp. 25-30). Galway: PSAI and ICSG.

Murray M., Grummell, B., \& Ryan, A. (Eds.). (2013). Further education and training: History, politics, practice. Dublin: MACE Press.

O'Farrell, C., \& Farrell, A. (2013). Emerging issues in higher education III: From capacity building to sustainability. Dublin: EDIN.

O'Shea A., \& O'Brien, M. (2011). Pedagogy, oppression and transformation in a 'post-critical' climate: The return of Freirean thinking. London: Continuum.

Pain, R. (2003). Social geography: On action-oriented research. Progress in Human Geography, 27(5), 649-657.

Petrick, K. (2015). Fast times in hallowed halls: Making time for activism in a culture of speed. Studies in Social Justice, 9(1), 70-85.

Piven, F. (2010). Reflections on scholarship and activism. Antipode, 42(4), 806-810.

Preston, P., \& Silke, H. (2011). Market 'realities': Decoding the ideology and discourses of neoliberalism. Australian Journal of Communications, 32(2), 1-20.

Rajan, R.G. (2010). Fault lines: How hidden fractures still threaten the world economy. Princeton: Princeton University Press.

Russell, C. (1993). Academic freedom. London \& New York: Routledge.

Ryan, A.B. (2011). Conscientation: The art of learning. In A. O'Shea \& M. O'Brien (Eds.), Pedagogy, oppression and transformation in a 'post-critical' climate: The return of Freirean thinking (pp. 86-102). London: Continuum.

Scarpetta, V. (2014). Meet the new Greek government. Open Europe. Retrieved January 272015 from http://openeurope.org.uk/blog/meet-the-new-greek-government/

Slaughter, S., \& Leslie, L.L. (1997). Academic capitalism: Politics, policies, and the entrepreneurial university. Baltimore: Johns Hopkins University Press.

Smeltzer, S. (2015). Interrogating course-related public interest internships in communications. tripleC: Commuinication, Capitalism and Critique, Open Access Journal for a Global Sustainable Information Society, 13(2), 509-525.

Smeltzer, S., \& Cantillon, S. (2015). Guest editors' introduction: Scholar-activist terrain in Canada and Ireland. Studies in Social Justice, 9(1), 7-17.

Sudbury, J., \& Okazawa-Rey, M. (Eds.) (2009). Activist scholarship: Antiracism, feminism, and social change. Boulder: Paradigm Publishers.

Townsend, J.G., Porter G., \& Mawdsley, E. (2002). Transnational community of nongovernment organizations: Governance or poverty reduction? Journal of International Development 14(6), 829-839.

Volpe, M., \& Chandler, D. (2001). Resolving and managing conflicts in academic communities: The emerging role of the 'pracademic'. Negotiation Journal, 17(3), 245-255.

Wickham, J. (2012, May). The role of sociology in understanding the current crisis. Presentation at the Sociology Association of Ireland Annual Conference, Maynooth University, Ireland. 